\title{
Articles
}

\author{
Alexander Panchenko
}

\section{Channeling, Agency, and Strategic Information: The "Semiotic Ideologies" of New Age Culture}

DOI: https://doi.org/10.22394/2311-3448-2020-7-2-4-23

\begin{abstract}
Alexander Panchenko - Russian Literature Institute (the Pushkin House); Russian Academy of Sciences (Saint-Petersburg, Russia). apanchenko20o8@gmail.com
\end{abstract}

One important aspect of religious practices and representations concerns the way information is handled. This article understands religion as a form of imagination, giving human properties to "nonhuman" agents (and vice versa), and thus, the rules of communication and interaction with such agents play a special role in religious culture. Webb Keane's theory of "semiotic ideologies" is one tool that facilitates the study of religious norms, expectations, and rules. In New Age culture, practices of "information exchange" with imaginary superhuman agents and transpersonal forces are based on specific psychophysical techniques, often called "channeling" or "contact." The analysis of specific ethnographic examples related to ufological channeling demonstrates that this practice forms new types of collective agency, a distinctive feature of New Age culture itself.

Keywords: semiotic ideologies, cognitive religious studies, agency, New Age culture, ufology, channeling.

This article was prepared with the support from a grant of the Russian Foundation for Basic Research, project No. 18-509-12017 ("New Religious Culture in Late Soviet and Post-Soviet Russia: Ideology, Social Networks, Discourses”). 


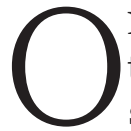
NE IMPORTANT aspect of religious practices and representations concerns the way information is handled. If one understands religion as a form of imagination, giving human properties to "nonhuman" agents (and vice versa), one can expect that the rules of communication and interaction with such agents play a special role in shaping religious culture. Indeed, the ritual norms, expectations, and rules that anthropologists of religion study can be viewed as the study of the needs (and problems) of that exchange of information between people and certain "otherworldly" (that is, nonhuman) beings and forces. This approach is equally applicable to prayer and fortune-telling, sacrifice and demonic possession, and child "summoning" and Spiritualist séances. Webb Keane's concept of "semiotic ideologies," which shifts a researcher's attention from the process of meaning and interpretation to its social prerequisites, conditions, and consequences, presents a convenient analytical tool for studying the aforementioned norms, expectations, and rules in this context (Keane 2003, 419). Keane's ideas facilitate the analysis of local and historically-conditioned methods of communication with the transcendent, as well as the comparison of different perceptions of media and material carriers of "otherworldly information." Below I will try to demonstrate some of the perspectives of this concept in relation to contemporary New Age culture.

In New Age culture, practices of "information exchange" with imaginary superhuman agents and transpersonal forces are based on specific psychophysical techniques, mainly "channeling" or "contact" (Hanegraaff 1996, 23-41; Wood 2007; Hammer 2001, 369-73, 393-401). "Channeling," as defined by British sociologist of religion Matthew Wood, is "a form of spirit possession in which the spirit is held to be a religious master of some sort (rather than an ordinary deceased human, as in spiritualism, or a deity, as in paganism or Pentecostalism), whose primary purpose is to deliver messages of general interest to humans regarding the current state of, and future changes to, the world and our place within it" (Wood 2007, 101). Researchers of New Age culture have long recognized the prominent place of channeling. According to Wouter Hanegraaff: “

There can be no doubt about its central importance in the genesis of New Age religion. Many of the fundamental New Age beliefs . . . have first been formulated in channeled messages. It is therefore fair to say that, in spite of the tendency among New Age believers to emphasize personal experience as the exclusive basis of religious truth, New Age religion must to a large extent be considered a religion of revelation [Offenbarungsreligion] (Hanegraaff 1996, 27). 
In such a generalized perspective, channeling, of course, does not differ much from prophecy, including prophecy as depicted in the JudeoChristian tradition. At the same time, it has a number of specific features and properties as an emic category.

The genesis of channeling is closely related to the history of Spiritualism and Theosophy, which proliferated in Western culture at the end of the nineteenth and in the first half of the twentieth century. In essence, channeling is a logical continuation of the Spiritualist technique, with the only difference being that it does not require any special devices, (e.g. a table with a pencil inserted in it), ritualized "séances," or the presence of a virtuoso pretending to possess the charisma of a "medium." Conveniently, anyone can be a channeler, although special abilities or training under an experienced mentor may also be required. This "democratism of revelation" in New Age culture is comparable to the perception of the gifts of the Holy Spirit in Pentecostalism. Nevertheless, in both cases, the information transmitted by prophecy becomes a discursive field for social competition and struggle.

Although initially supported, Wood's claim that channeling did not imply communication with the "ordinary dead," but rather with "spiritual teachers" has begun to be scrutinized (Hammer 2001, 380-82). Initially, it had a number of supporters. Helena Blavatsky argued that she received the "secret doctrine" and Elena Roerich the "living ethics" from "ascended masters" or "teachers of eternal wisdom," that is, from human beings who differed not only in their degree of spiritual development, but also in their paranormal abilities (telekinesis, telepathy, etc. . .). Thus, the technologies of "communication with the otherworldly" used by Blavatsky and Roerich generally inherited the practices of Spiritualism, but significantly changed the status of the addressees: they were not ordinary people, but superhuman beings with special knowledge and capabilities. Jane Roberts, for example, received "spiritual knowledge" from Seth, an "energy personality essence" (Roberts 1970, 13). Here, however, the idea of individuality was quite different from that of Theosophy. One of the most significant innovations in New Age anthropology is a kind of "distribution of agency," whereby any personal consciousness is a part of the one God or the universal soul (Hanegraaff 1996, 207-10). This approach, of course, makes it more difficult to distinguish between addresser and addressee, but does not deny them individual agency. The channeler, however, seems to double, as the principle of "self-divinity" (Klin-Oron 2015, 363-65), implying that he or she is both an ordinary person and a superhuman agent at the same time, or, in Mar- 
shall McLuhan's terms, both a medium and a message. "In sum," notes Hugh Urban, "it is not simply the medium who is the message - that is, both the spokesperson for the divine and herself divine; rather, we are all the message insofar as we are each potential channels for the divine transmission of our own inherent godliness" (Urban 2015, 326).

Channeling practices, however, also involve interaction with more familiar types of agents, namely beings from extraterrestrial civilizations, who "like benevolent deities, . . . care about the planet Earth, ... about the human race, ... about human politics, and . . . about the well-being of individual humans" (Partridge 2015, 390). According to Christopher Partridge, aliens have become significant characters in the Western occult and may even assist in communication in both the Spiritualist and the Theosophical tradition (Partridge 2015, 39495). However, it is among channeling practices, whose formation and spread coincided with the "ufological boom," that extraterrestrial civilizations functioned as important communication partners for individuals, nations, and humanity as a whole.

Thus, the recipients of channeling can be "spiritual teachers," aliens, or holistically understood transpersonal forces. The boundaries between these types of agents are often rather blurred, especially as practitioners are free to address all of them. In this context, it is fair to speak not only about the similarity of channeling with the practices of Spiritualism and Theosophy, but also about its specifics. Discussing the media-specific features of channeling, Urban suggests that this form of religious revelation "was uniquely adapted to the new environment of television, where the medium really was the message. ... Although there is now a good deal of literature on the subject of religion and television ... , channeling represents perhaps the most explicit but ironically unexplored example of this spiritual-technological interface" (Urban 2015, 321). Although this analogy between channeling and TV channels may not seem obvious, the media specificity of religious revelation in New Age culture certainly deserves attention.

In her research on religion and media in the modern world, Birgit Meyer suggests using the term "sensational forms," which complements the concept of semiotic ideologies. According to Meyer:

Sensational forms are relatively fixed modes for invoking and organizing access to the transcendental, offering structures of repetition to create and sustain links between believers in the context of particular religious regimes. These forms are transmitted and shared; they involve religious practitioners in particular practices of worship, and play a cen- 
tral role in modulating them as religious moral subjects and communities (Meyer 2013, 315).

In other words, unlike Keane's approach, which implies special attention to the typology of signs and conventional methods of their interpretation, Meyer's concept considers the role of media and the social in organizing religious experience. Proceeding from this, she builds a typology of "modalities of media" characteristic of various "religious regimes." If the boundaries between the medium and the message are not quite clear, i.e. in the case of icon worship, where the material object is not separated from the "spiritual forces" it embodies, the medium tends to "disappear." If the (in)appropriateness of an existing medium becomes the subject of discussion and/or alternative options appear, i.e. in the reception of sacred images and biblical text by Protestants, it is permissible to speak of "contested" media. Finally, media can become "hyper-apparent": this is particularly the case with the use of modern communication technologies in charismatic Christianity (Meyer 2013, 317-20).

This model encounters some difficulties, however, when applied to channeling practices. On the one hand, since the medium here is always the contactor himself, who, according to Urban's idea, turns into something like a TV with a set of channels, it seems possible to claim the disappearance of media. On the other hand, the abovementioned agents, who act as channeling addressers, refer to slightly different modalities of media. In my opinion, the disadvantage of Keane's and Meyer's approaches is that they do not pay sufficient attention to the types of and cognitive characteristics of the agents involved in the informational exchange with the transcendent. Thus, it seems that additional analytical tools are needed

It is necessary to return to more general issues of human interaction with "invisible partners" in "religious communication." The semiotic ideologies on which these practices are based imply a close link between the cognitive status of communicators, the significance of information, and the means of transmission. This interdependence is clearly demonstrated by Pascal Boyer, who believes that the characters of the religious imagination have the status of full access agents (FAA) - agents with "full access to strategic information." He writes:

Strategic information is the subset of all the information currently available (to a particular agent, about a particular situation) that activates the mental systems that regulate social interaction. [. . . I In social interac- 
tion, we presume that other people's access to strategic information is neither perfect nor automatic. [.. .] There is a general difference between our intuitive representation of humans we interact with and our intuitive representation of supernatural agents. The latter are full-access strategic agents - agents whom one construes as having access to any piece of information that is strategic. That is, given a particular situation, and given some information that activates one's inference systems, one assumes that the full-access strategic agent has access to that information (Boyer 2001, 152-58).

In other words, access to strategic information is a prerequisite for choices in any social situation. This is not simply about the FAA's omniscience, but also the fact that their knowledge and actions are critical to individual and collective actions. Boyer, in particular, illustrates this idea with the following example. If one compares the two statements - "God knows the contents of every refrigerator in the world" and "God knows you are lying" - the second statement is more familiar and more significant. However, in certain contexts, the contents of the refrigerator will also matter, for example, "if that includes items you stole from your neighbors" (Boyer 2001, 158). According to Boyer, the human brain easily (without resorting to complex inferences, but following intuitive patterns) distinguishes between strategic and nonstrategic information, as well as differences between FAAs and all other imaginary and non-imaginary agents.

In general, these considerations by Boyer (as well as his concept of religion more broadly) imply a more parasitic view of the FAA. "What is 'important' to human beings, because of their evolutionary history," he argues, "are the conditions of social interaction: who knows what, who is not aware of what, who did what with whom, when and what for. Imagining agents with that information is an illustration of mental processes driven by relevance. Such agents are not really necessary to explain anything, but they are so much easier to represent and so much richer in possible inferences that they enjoy a great advantage in cultural transmission" (Boyer 2001, 167). In other words, FAA images are primarily used in culture to perform, say, emphasize, and legitimize. Boyer suggests three types of such agents - "legislators," "exemplars," and "onlookers" - emphasizing that the latter type is usually at the center of all religious practices.

It is worth asking, however, what kind of information these interested onlookers share with humanity. In one situation, a demon-possessed woman may report the name of a village sorcerer who harms 
her fellow villagers; in another, she may report the special hatred that demons have toward the Orthodox, thus asserting the primacy of Orthodoxy over all other Christian denominations. It is clear that the discovery of a harmful sorcerer is directly related to strategic information and the social choice of community members. The topic of "the triumph of Orthodoxy," however, may or may not be related to such a choice - here, as in the case of refrigerators, everything depends on context. Often, however, information shared with people by such agents is purely abstract and often unlikely to be perceived as strategic. The most obvious example is Pentecostal glossolalia, where the semiotic status of speech is not in itself disputed, but the difficulty or impossibility of deciphering it is. The Holy Spirit speaks likely important but incomprehensible things with the mouth of a possessed person. A few other factors are also important here: the anthropomorphism of the consciousness of the FAA, his or her presence in a particular community, and with whose mouths he or she speaks.

Boyer probably should have more thoroughly discussed the FAA's motives and intention, in short were they "good" or "evil." Clearly, this binary is not exhaustive - especially in the perspective of a cognitive approach, where the manifold goals and intentions of the "interested observers" vary based on the people with whom they have to deal. Their initial intentions, however, can be described in terms of aggression and benevolence, harm and benefit, as well as sincerity and deception.

On the basis of these considerations, I have formulated three principal questions with which to explore obsession and revelation in the context of local semiotic ideologies:

1. Why do FAAs in some religious communities use the human body to communicate with believers, while those in other communities do not?

2. Why do FAAs report strategic information in some cases and not in others?

3. How do the expected intentions and behavioral strategies of the FAAs correlate with the nature of the information transmitted?

The first of these questions is the subject of quite a lot of research, which offers quite different answers (Boddy 1994, 407-34; Cohen 2007, 59-97; Huskinson and Schmidt 2010, 1-15; Halloy and Naumescu 2012, 155-76). One of the most common (albeit often criticized) approaches uses neo-Marxist rhetoric. In the words of James Scott, spirit possession is the "weapon of the weak," a means of symbolic resistance against social, economic, or gender domination (Lew- 
is 1966, 307-29). In this perspective, the charisma of either the possessed or of a prophet, who opposes the routine social structure, turns out to be a gift that makes it possible to acquire a new status and influence, to bypass existing norms, and so on. Another interpretive model of obsession, formulated by Janice Boddy and built upon the ideas of Bourdieu, Gramsci, and Foucault, is nearly the opposite. Criticizing medicalizing and functionalist approaches to obsession research, Boddy (as well as a number of other researchers) focuses on the embodiment of spirits as a paradoxical means of maintaining and reproducing moral and gender norms:

The possessed learn a spirit anti-language that metaphorically alters quotidian terms. . . Zar is at once a healing rite and a parodical means to domesticate male and alien powers, an ambiguous metacommentary on local morality, and a history and anthropology of life in colonial and post-colonial Sudan. I accent its comedic and aesthetic dimensions by comparing it to satirical allegory, where the historical consciousness of the village is vividly dramatized in challenging but also reinvigorating its embodied, engendered, moral order (Boddy 1994, 417).

I think, however, that the social drama of possession, revelation, and prophecy operates with a more intricate set of roles and behavioral strategies. How and why do glossolalia and meaningful prophecies coexist in the same community? How different are the ways and practices of interpreting the speech and behavior of a possessed person in terms of functionality? How do semiotic ideologies combine perceptions of the verbal and action?

Without trying to answer all these questions, I will try to apply this model to the practice of channeling. Before diving in, it is necessary to say that in his arguments Boyer mainly considers examples from archaic cultures and world religions, and does not pay special attention to New Age and other forms of present-day postsecular culture. He does pay some attention to aliens, but does not discuss channeling as a special practice:

Although many people seem to accept the existence of such beings and the surprisingly efficient governmental cover-up, there are no specific rituals directed at the aliens, the belief seems to trigger in most people no deep emotional commitment, no significant change in lifestyle, no intolerant notion that $w e$ are better because $w e$ believe in aliens. If I may speculate, I would add that in the most popular version these aliens are 
not described as having what I just defined as strategic knowledge. That is, although the aliens are described as smart fellows with advanced knowledge of physics and engineering, this somehow does not seem to trigger the inference that they know that my sister lied to me or they know that I filed an honest and accurate tax return. The way believers acquire and represent the "evidence" for alien visits seems to have no bearing on individual behavior.

In contrast to this, a small number of people actually represent aliens in the same way as gods and spirits. In some cults what the aliens know and want makes a huge difference to people's lives. What you can do and how you do it, the way you live and the way you think are all informed by thoughts about the aliens (Boyer 2001, 166).

These statements can hardly be considered ethnographically correct. The "emotional commitment" related to belief in aliens, both in the United States and elsewhere, seems to be characteristic of more than just small and marginal groups like the Heavenly Gate, whose members committed suicide in 1997 to go to the spaceship accompanying the Hale Bopp comet (Zeller 2014). In fact, "ufological" beliefs and practices are an important part of modern mass culture (Lewis 1995; Partridge 2003; Palmer 2004; Reece 2007; Lepselter 2016). Although I cannot judge what percentage of people give aliens FAA status, both "UFO religions" and channeling practices seem to imply more complex variations in agency, including its relationship to imaginary strategic information. To look at this problem in a slightly different way, maybe scholars should consider separately the status of the FAA and the degree of their involvement in human life (or, in other words, belief in their presence). In this sense, theism and deism represent two poles of the collective imagination, between which there can be some sort of intermediate emotional and cognitive models.

The practice of channeling, as a rule, does not deal with glossolalia, but here too, the messages of "invisible partners" are often not very meaningful. They can abound in repetitive moralistic maxims and quasi-scientific reasoning, seemingly unrelated to "strategic information." At the same time, one of the significant and expected leitmotifs of channeling is the theme of a new epoch, which implies impending catastrophes and the physical rebirth of the human being. This often entails quite specific forms of social choice, such as strict dietary prescriptions or a code of conduct. Here, however, it should be assumed that the same medium (whether Pentecostals, "contactors," or some other type of revelation) can transmit different messages in different 
contexts in a meaningful (and probably functional) manner. To test this assumption, special and rather painstaking ethnographic work is needed, but even without it, it is possible to try to draw some conclusions based on more disparate materials. Below I will give an example of the mutual connection between the status of channeling recipients, the content of their messages, and the social context of post-Soviet culture.

The example centers on the history of the "Vissarion movement" or the Last Testament Church (hereafter referred to as the LTC) (Panchenko 2011, 119-45). The Church was founded in 1991 by an amateur artist from Minusinsk named Sergei Torop (b. 1961), who claims to be Vissarion, a new incarnation of Jesus Christ. Despite his Christian entourage, known as "the Fulfilment," the LTC's activities, ideology, and the practices are directly related to the culture of the late Soviet New Age, and the movement itself emerged from channeling sessions. Minusinsk was a hub of New Age religion: in 1989 Y. I. Yaklichkin ran "Hypothesis," a club that united ufology and paranormal enthusiasts. In the late 1980 os similar clubs, which functioned as local New Age centers, appeared in many cities of the USSR. The scope of activity of Minusinsk's "Hypothesis" was quite broad: it led visits and conducted "research" into various "anomalous zones" (including the socalled "Perm Anomalous Zone," where, according to ufologists, UFOs and other unusual objects had been repeatedly observed); collected information about "paranormal phenomena," including now-forgotten "poltergeists" (Iaklichkin 1996); and it performed various methods of alternative healing (Ol'khova 1996). Channeling was also practiced at the club, mostly with extraterrestrial civilizations.

In 1990, Sergei Torop joined the club. This is what Yaklichkin himself had to say about it in an interview with a Krasnoyarsk journalist:

Vissarion (Sergey Torop) and his friend Vladimir Plesin were members of our club in 1990. He did not stand out from the crowd of 100 people. Then, we were just trying to make contact. It was not entirely clear to us with whom we were in contact. Some said it was with gods, others said it was with aliens. [. . .] A number of experiments were carried out and in one of them Plesin made contact. When a person makes contact, he writes a report on how it all happened, on what he saw, and on how he got the information. In general, we received information on the substance of the contact. But then we noticed a strange thing: as soon as Plesin made contact, he immediately began to change. He began to receive information about a new religion that was focused on space. In the 
end, he separated himself from us. [. . .] In our research on anomalous zones, poltergeists, and contact forms, we found that the contact was not with gods, not with other civilizations, but with other life forms that have a spherical structure. They are recorded on video and captured in photographs. Sometimes they can even be observed visually. This life form was a completely different matter, unfamiliar to us in its physical properties. It is aware of our biology, our constitution, and it can enter into our consciousness and program it. By the way, zombies are the product of these very creatures (Ol'khova 1996).

However, Plesin himself, in his book The Good News, which recounts the first years of "Fulfillment," recalls what happened at "Hypothesis" in a slightly different way:

In December 1990, he [Vissarion] appeared for the first time in the lives of many people, including those engaged in ufology. Among them was Vladimir, who had absolutely no thoughts about any religious teaching, let alone comprehension of it. That day, expedition members told the audience about the results of the trip to the anomalous zone of Perm. Among the speakers was Vladimir Plesin, who said that according to the information collected from the extraterrestrial world, a new evolutionary stage in the development of mankind would come, which no one could avoid. [. . . ] At the end of the meeting, Vissarion came to Vladimir and asked quietly: "Wasn't it the external world that said the Fulfillment would begin after January 1991?” [. . . ] After a while, on New Year's Eve, Vladimir came to Vissarion's house. [. . . ] And to the question asked earlier, Vladimir brought forth the answer, revealed to him by the Universe, : "We know about Vissarion. He is the One who will lead humanity to Spirituality and Unity.” (Plesin 1998)

The Last Testament (Poslednii zavet), the sacred book of the LTC, which contains the chronicle of the "Fulfillment," describes the same episode as follows:

Vladimir Minusinsky, who stayed next to the Teacher on all His trips, had a peculiar feature: his consciousness was able to perceive information from the extraterrestrial world, from external sources, invisible to the human eye. [. . .] In December 1990, when Vladimir saw Vissarion, the man who had once visited the ufological center and modestly watched one of its meetings, he immediately took an interest in this unusual man. Soon extraterrestrial sources told him that Vissarion was 
the One who would lead mankind to salvation. [. . .] Shortly thereafter an event occurred in Vladimir's life that changed the quality of the information he received: he heard the voice of the ancient prophets, who live in the invisible world, in the midst of the living on the Earth, and strive to achieve their own presence and to use their wise voice to help people. Vladimir not only heard them, he also saw them. And his heart saw a significant difference in the quality of communication with the extraterrestrial world, with the nonhuman world, and with the circle of saintly brothers, left by the Will of the Great Father in a subtle and material body to aid man. For a human warmth emanated from the ancient prophets, a warmth of heart that in its essence was unrelated to a rational, strict, and logical extraterrestrial world. [. . .] And sometimes with a strict word, the saintly brothers pointed out to their brothers living on the Earth their carelessness in comprehending the Truth or told them about the times when the righteous gave their lives for the Truth of God (Poslednii zavet. Povestvovanie ot Vadima, n. d. Pt. 2, ch.3, 63-74).1

Thus, Plesin received information on Vissarion's divine mission from extraterrestrial addressers. Soon, however, these extraterrestrials were rebranded as "ancient prophets" also known as the "saintly brothers." Plesin himself wrote in his book: "Many lines in scripture are written in the name of the Saints and prophets of the Lord, of whom you know from the scriptures of the ancients. By the will of God, these twelve Caesars of Heaven, as well as Mother Mary, remain in the midst of us in the spirit of subtlety, fulfilling their destiny" (Plesin 1998). It was Vissarion who prompted this transition from one type of agent to another. ${ }^{2}$ Vissarion also mentions the "holy brothers" in his meetings with his followers:

Can an astral body last longer [than a physical one]? Only by the will of the Heavenly Father. If it is necessary to use you to help people, you may

1. The quotations from the Last Testament (Poslednii zavet) given in the paper are from an electronic version prepared by the LTC members.

2. In his recent autobiography, (“Znakom'tes', takoi vot ia” [Meet Me, This I Am], 2017), published on his personal web-site, Vissarion does not mention that his divine mission was reported to Plesin by aliens and only speaks of an "Old Testament prophet.": "As Vladimir himself, who was in my house at the time, later on told me, his so-called psychic abilities allowed him to see suddenly an unusual for him appearance of a nice old man, who introduced himself as one of the famous Old Testament prophets. Through Vladimir, he conveyed to me, in a poetic and intricate form, a kind of message, in which, among other things, he expressed his advice that I should use the name Vissarion, which, thinking later, I agreed with.” http://vissarion.name/znakomtes-takoj-vot-ya/. 
be left with a material life force that can help people. A more complete fulfillment in such a state is performed by the Holy Brothers. You call them fathers, but this is not true: they're your Brothers, you have only one Father, who is in Heaven. The Holy Brothers are some of God's children from the times of the Old and New Testament. By the Will of God, the twelve Brothers were left on earth to help people, and miraculously could be seen by many chosen ones. In addition to them, My Mother Mariam was also left behind according to God's Will in the name of Fulfillments (Last Testament. Meetings. Ch. 2, 24).

It is difficult to determine to which specific historical characters Vissarion is referring. There could be many sources for this image: from the twelve "minor" Old Testament prophets revered in the Russian Orthodoxy to the twelve church fathers according to the Fifth Ecumenical Council. It is ironic that Plesin's "twelve Caesars" can be interpreted as an allusion to Suetonius's work, whose heroes were anything but moral leaders of humanity. Thus, in this case, the agents were of an "anthropomorphic type," like the "ascended masters" of Blavatsky and Roerich.

Furthermore, although Vissarion received the first messages about his divine mission from aliens, he soon began to criticize this type of channeling as dangerous and damaging to humanity. His opinion shifted because often alien civilizations desire to destroy humanity and intentionally send "false information":

Now there is much talk of contacts with space. Can we believe them? If they believe they're communicating with the Extraterrestrial Mind, that's the truth. And if you believe what they learned during the conversation, you should know that almost no one will get serious truthful information. And in recent times, this has been understood by people who are in most close contact with such phenomena. They were able to deduce that almost all the information coming to the Earth was false. But from now on, there will be a great multitude of people communicating with the universe. And the inner essence of these people will be such that they will quickly believe that they are the ones who receive the truth. This bitterness has yet to be felt by the majority of mankind but trouble is not far off. Contacts between your children and extraterrestrial worlds will be especially dangerous (Last Testament. Meetings. Ch. 1, 105).

Vissarion had his own reasons for taking this position. First of all, this conflict should be interpreted in Max Weber's terminology as a con- 
frontation between routine and charismatic power. Vissarion, who calls himself the "Word of the Heavenly Father," could now claim to be the principal and only channeler. In such a case, the boundaries between the medium and the message disappear completely, so that Vissarion represents the physical embodiment of the FAA. Alternative "channels of communication" with any FAA are not only redundant, but also challenge Vissarion's conventional status. In practice, however, during the first decade of the LTC's existence, many of his followers continued to engage in channeling with aliens and to exchange information they received from outside contactors. As far as I can see, these messages were often related to several waves of eschatological panic, which had a rather noticeable impact on the daily life of the LTC (including the popularity of very strict dietary prescriptions, which endured until the mid-200os). This panic stemmed from an increasing expectation of planetary accidents that not only would transform the Earth, but also would lead to a physical change among a small portion of mankind and the destruction of the rest. Vissarion's own authority was not enough to put an end to these panics, and in 2001 the official newspaper of the LTC published the reports of the "Intergalactic Council for the Salvation of the Earthlings," designed to reassure members of the church who expected a catastrophe in the near future.

In the second half of the 2000s, the intensity of eschatological expectations among Vissarion's followers decreased significantly and, at the same time, interest in channeling with aliens decreased. Vissarion's position on the dangers of such contacts seems to have become increasingly shared, as is evident from interviews with members of the LTC in 2007:

I turned on through Kashpirovsky. It wasn't Kashpirovsky who turned it on. There's another source still working through it.

Interviewer: Which one? What source is working through it?

In my understanding?

Interviewer: Yes.

Virtues in quotation marks . . . in quotation marks. Luciferic direction. There are civilizations that the Bible called Lucifer, an angel. This is one of the directions of the higher mind, which sees humanity as a tumor and tries to get rid of us with our own hands. And that's the source. The only civilization trying to get rid of us is the Lucifers. It's a Lucifer concept, it's . . . It's the only thing you can call it. If we talk about their representatives, you should know these representatives. They send bioandroids here all the time. 


\section{Interviewer: Bioandroids?}

Here we go, green guys. These are their materialized copies.

Interviewer: Of Lucifers?

Yeah. That's exactly what they are, but that's not their essence. They're like that, but it's their doppelganger. They are materialized, they have great abilities, they use their . . - - what's in their head - and we are unreceptive to everything. And these guys, they're sending this stuff in here, which is doing their tasks. And then they just leave. That's already known. Previously, it was closed, it was secret - top secret-now it has all come to the surface, all of it is known. These guys were the ones who were doing the tasks on these. .., on the plates of the so-called spacecrafts, which fell into the hands of people ... and they were making their own conclusions accordingly, as it turned out (P., A. 2007, Panchenko and Shtyrkov, v. Cheremshanka, Kuragino district, Krasnoyarsk region, August 29).

Another interview with a "contactor" demonstrated that channeling with extraterrestrial civilizations was not only spiritually but physically harmful:

Everyone decides for themselves, but the Teacher says it is better not to do it. Don't mess around, because, yeah, anyone can connect. And [there are] those who want to help you, and those who want to kill you. That's why it's better not to get carried away. [. . .] We have a man here in the village. In his time, he was in contact with some civilization. Yes. And the Teacher told him to stop doing it, and his flesh started to fall apart because [. . .] He really started to fall apart because he was taking it all through the bone . . musculoskeletal apparatus, i.e., through the bones. His bones were starting to fall apart. He started to walk badly, his hands were bad . . . Well, he stopped it on the Teacher's recommendation. He's straightened out now, yeah. He was still walking with a stick, with a crutch a year ago, but now he's moving fine. [. . .] The Teacher's attitude is that it is better not to do it, better not to spoil it. A lot of people have come from the secular world already - they're messing with it. But right now, I think most people have this disease cured (K., G. 2007, Panchenko and Shtyrkov, v. Tayaty, Karatuzsky district, Krasnoyarsk region, September 2).

In the words of the woman who told this story (who had never been "in contact"), channeling appears to be something akin to dangerous demonic possession. Interestingly, the topic of television also appears, although not quite in Urban's terms: 
It was very hard to back off. Quitting, was very difficult. She went to our priests, talked to them, and was told, "Well, yes, there is a place for that, but you have to deal with it yourself. And here are the methods that are being used to cope there - the state of prayer, straight away - "no, no, I don't want to, leave me alone" - these are the methods of preparing yourself. I mean, so that the law of freedom of choice is not violated. As the Teacher says, many civilizations are trying to get in touch with us, but they have no right to violate the law of freedom of choice. They may be trying to get in touch with you, but if you say no, they leave you alone. [...]

That's exactly what's going on. Some people are shown pictures. That's who. . . that's who they've been trying to get in touch with, they tell how painful it is. They even show pictures. There's one woman here, now she's not here, she's on the payroll, she says, "Here I was in the tent, and suddenly these pictures came up. It's just like a TV all over the tent, so it's panoramic. They come up with pictures and thoughts that inspire and inspire you. And," she says, "it's literally the head that boils." She rushed out of the tent, and says, "brrr," and began to pray. Well, here she is, she too, left this contact (K. G. 2007, Panchenko and Shtyrkov, v. Tayaty, Karatuzsky district, Krasnoyarsk region, September 2).

Such an attitude toward mental contacts with alien civilizations in the LTC did not at all imply that the practice of channeling had disappeared from the daily lives of Vissarion's followers. Channelers, however, sought out other types of addressees - the souls of deceased relatives and acquaintances - and thus the content of the broadcast underwent some changes.

We've got some people talking to the souls of the dead. Not many, but there are some. You know, see, or whatever. . . Feeling. Within forty days, these souls may somehow come into contact with their loved ones who live here. And now I think someone at P.'s father's house said that it is advisable when you see your soul there, to stand in a circle, to light candles, to stand in a circle and wish: "Fly high, fly far, fly to the Father." It seems to help the soul a lot. And somehow it went like this in the [New] Promised Land, so guys if it helps the soul to get away from the earth, let's practice it. [...]

K.'s sister just left. "We,” he says, "are sitting here, remembering her. Oh, how beautiful she was, then, yes, sir." And they [the sisters] - one has the gift of seeing since she was six years old, and K. . . just feels it. "And," she says, "the answer is, why 'she was'? Why are you talking 
about me in the past tense? I'm alive, I'll be alive forever. And. . . and you'll remember that we're going to be here forever, that we're not dying. The soul does not die, the soul is eternal, don't talk about us in the past tense. [...]

Oh, yeah, here's what else she said. What I have to go through, her sister said. [. . .] I think my sister told her, "I've got to go through twenty-four steps of ordeal here." Here you go. And they're in a circle, too K. - they're in a circle. And they sang twenty-four psalms. And one of the sisters, who has been seeing since she was six years old at K.'s, says she saw “Our sister's, - says, - such a husk, such dirt flew off at this time. They sang twenty-four psalms to make it easier for her to do all these twenty-four steps of ordeal (K., G. 2007, Panchenko and Shtyrkov, v. Tayaty, Karatuzsky district, Krasnoyarsk region, September 2).

T.'s got an aunt in St. Petersburg or something, so she's gone. And a woman, who lives in Cheremshanka, she's got contact with her soul. Here, after the [Good Fruits] Holiday. [. . .] And, this means that this holiday was happening for the first time in the universe on such a scale, very big. All the authorities were there, everybody. . . The bright forces from all the planes were here with us. And, in general, a holiday of light forces is of very large scale like this- that's how it was said. Which means that a new stage begins in the development of the Earth or something. And the Teacher is changing now, and the Earth is changing its vibrations. Even people who know, don't know, feel, don't feel, even earthlings, all this also affects them. And two key phrases even accompany this new stage [. . . Oh, there was something first there, that you pay a lot of attention to trifles because everything is built of trifles. And I forgot the other one. But, in general, it's like nothing special, maybe that's why I didn't even remember it anymore. But the fact that the Holiday was a very large-scale event, and all the angels were here. . . This is what she conveyed through this woman in Cheremshanka (B., L. 2007, Panchenko and Shtyrkov, v. Tayaty, Karatuzsky district, Krasnoyarsk region, September 2).

Although the latter example also deals with events of planetary importance (which is rather typical of the messages from extraterrestrial civilizations), the focus here is shifted to the daily ritual life of the LTC - specifically, the annual holiday commemorating Vissarion's first sermon. As for the other stories, they should also be interpreted primarily in the ritual context - as a means of legitimizing the nascent funeral ritualism of the LTC. In this case, it is unlikely that one can attribute FAA status to the souls of the deceased. 
Both this and similar examples demonstrate that aliens interacting with post-Soviet contactors in the 1990 and 2000 s usually predicted a universal catastrophe and the coming renewal of humanity. At the same time, they can hardly be classified as "punitive gods," whose access to strategic information (especially negative information) is directly related to the nature of their actions toward individuals and humanity. ${ }^{3}$ Rather, external forces and sometimes even the people themselves, particularly their negative deeds and thoughts, are seen as the cause of catastrophic changes. This means that the three types of agents (aliens, "teachers," and the souls of the deceased) with whom the "contactors" of the LTC have interacted and are interacting, are "responsible" for different blocks of information. Aliens report an impending eschatological catastrophe and ways to survive it, "teachers" are primarily concerned with personal spiritual growth and do not address humanity as a whole, and the souls of the deceased offer information of a "private" nature significant for the development of family and community ritualism. I believe that these differences reflect specific types of agency - "individualized" in the case of "teachers," "collectivized" in the case of aliens, and "privatized" in the case of the souls of the deceased. This observation, at least in the post-Soviet context, makes it possible to conclude that the notion of New Age culture as highly individualistic is not entirely correct. In fact, practices such as channeling are successfully adapting to local ideologies and forms of socialization. It is indicative that LTC "contactors" were less interested in messages regarding the idea of "self-godliness," yet the holistic view of an individual as part of the transpersonal consciousness was quite popular. Vissarion is in fact the only "self-godly" creature in the LTC, and his followers can transform their agency through the meditative practice of "merging with the Teacher," which is partly reminiscent of channeling, but does not imply any direct exchange of information.

It is obvious that we are dealing with rather complicated (especially in the procedural and diachronic perspective) forms of supplemental distribution of different types of agency. How typical such a situation is in modern New Age culture, what the specific socio-economic factors are that determine the configuration of this distribution, and how it is comparable with other types of religious practices and representations in the past and present is the topic for further research.

3. On "punitive gods" see Purzycki, Finkel, Shayer, Wales, Cohen, and Sosis 2012, 84669; Norenzayan 2013. 


\section{References}

B., L. 2007. Interview recorded by A. A. Panchenko and S. A. Shtyrkov, v. Tayaty, Karatuzsky district, Krasnoyarsk region, September 2.

Boddy, J. 1994. "Spirit Possession Revisited: Beyond Instrumentality." Annual Review of Anthropology 23: 407-34.

Boyer, P. 2001. Religion Explained: The Evolutionary Origins of Religious Thought. New York: Basic Books.

Cohen, E. 2007. The Mind Possessed: The Cognition of Spirit Possession in an Afro-Brazilian Religious Tradition. London: Oxford University Press.

Halloy, A., and V. Naumescu. 2012. "Learning Spirit Possession: An Introduction.” Ethnos: Journal of Anthropology 77 (2): 155-76.

Hammer, O. 2001. Claiming Knowledge: Strategies of Epistemology from Theosophy to the New Age. Leiden: Brill.

Hanegraaff, W. J. 1996. New Age Religion and Western Culture. Leiden: Brill.

Huskinson, L., and B. E. Schmidt. 2010. Introduction to Spirit Possession and Trance: New Interdisciplinary Perspectives, 1-15. New York: Routledge.

K., G. 2007. Interview recorded by A. A. Panchenko and S. A. Shtyrkov, v. Tayaty, Karatuzsky district, Krasnoyarsk region, September 2.

Keane, W. 2003. "Semiotics and the Social Analysis of Material Things." Language \& Communication 23 (3-4): 409-25.

Klin-Oron A. 2015. "Individual Power, Cultural Constraints: Israeli Channeling in Global Context." In Handbook of Spiritualism and Channeling, edited by C. Gutierrez, 362-89. Leiden: Brill.

Lepselter, S. C. 2016. The Resonance of Unseen Things: Poetics, Power, Captivity, and UFOs in the American Uncanny. Ann Arbor: University of Michigan Press.

Lewis, I. M. 1966. "Spirit-Possession and Deprivation Cults." Man 1: 307-29.

Lewis, J. R., ed. 1995. The Gods Have Landed: New Religions from Other Worlds. Albany: State University of New York Press.

Meyer, B. 2013. "Mediation and Immediacy: Sensational Forms, Semiotic Ideologies, and the Question of the Medium." In A Companion to the Anthropology of Religion, edited by J. Boddy and M. Lambek, 309-26. Oxford: Wiley-Blackwell.

Norenzayan, A. 2013. Big Gods: How Religion Transformed Cooperation and Conflict. Princeton, NJ: Princeton University Press.

Ol'khova, N. 1996 "My zakliuchili dogovor s parallel'nym mirom" ["We made a contract with the parallel world"]. http://www.x-libri.ru/elib/innet189/o0ooooo1.htm

Ol'khova, N. 2001. Pakhari russkogo torsionnogo polia. 2001. [Plowmen of the Russian torsion field] Komok. Krasnoyarsk. 22.01.2001 (see also online publication: http:// www.x-libri. ru/elib/smi357/ooooooo1.htm).

P. A. 2007. Interview recorded by A. A. Panchenko and S. A. Shtyrkov, v. Cheremshanka, Kuragino district, Krasnoyarsk region, August 29.

Palmer, S. J. 2004. Aliens Adored: Rael's UFO Religion. New Brunswick, NJ: Rutgers University Press.

Panchenko, A. A. 2011. "Morality, Utopia, Discipline: New Religious Movements and Soviet Culture." In Multiple Moralities and Religions in Post-Soviet Russia, edited by J. Zigon, 119-45. New York: Berghahn.

Partridge, C., ed. 2003. UFO Religions. London: Routledge. 
Partridge, C. 2015. "Channeling Extraterrestrials: Theosophical Discourse in the Space Age.” In Handbook of Spiritualism and Channeling, edited by C. Gutierrez, 390-417. Leiden: Brill.

Plesin V. 1998. Blagaia vest’. [The Good News]. St. Petersburg. http://vissarion.chat.ru/ books/.

Poslednii zavet. Povestvovanie ot Vadima. n. d. http://slovo.vissarion.ru

Poslednii zavet. Vstrechi. n. d. http://slovo.vissarion.ru

Purzycki, B. G., D. N. Finkel, J. Shayer, N. Wales, A. B. Cohen, and R. Sosis. 2012. "What Does God Know? Supernatural Agents' Access to Socially Strategic and Non-Strategic Information." Cognitive Science 36 (5): 846-69.

Reece, G. L. 2007. UFO Religion: Inside Flying Saucers Cults and Culture. London: I. B. Tauris.

Roberts, J. 1970. The Seth Material. Englewood Cliffs, NJ: Prentice Hall.

Urban, H. 2015. "'The Medium is the Message in the Spacious Present': Channeling, Television, and the New Age." In Handbook of Spiritualism and Channeling, edited C. Gutierrez, 319-39. Leiden: Brill.

Urban, U. 2015. New Age, Neopagan, and New Religious Movements: Alternative Spirituality in Contemporary. Berkeley: University of California Press.

Wood, M. 2007. Possession, Power and the New Age: Ambiguities of Authority in Neoliberal Societies. Aldershot: Ashgate.

Yaklichkin Iu. I. 1997. Askizskii poltergeist (Posobie dlia spetsialistov, izuchaiushchikh fiziku anomal'nykh iavlenii) [Askiz Poltergeist (A Manual for Specialists Studying Physics of Paranormal Phenomena)]. Moscow: Profizdat.

Zeller, B. E. 2014. Heaven's Gate: America's UFO Religion. New York: New York University Press. 